How much does the physician's sex matter to lesbians? Can Fam Physician.1994 May;40:908-20.

5. Harrison $A E$, Silenzio VM. Comprehensive care of lesbian and gay patients and families. Prim Care.1996 Mar;23(1):31-46.

6. Kalra G. Pathologising alternate sexuality: shifting psychiatric practices and a need for ethical norms and reforms. Indian J Med Ethics. 2012 OctDec;9(4):291.

7. Dunji-Kosti $B$, Pantovi $M$, Vukovi $V$, Randjelovi $D$, Toti-Poznanovi $S$, Damjanovi $A$, Jašovi-Gaši $M$, Ivkovi $M$. Knowledge: a possible tool in shaping medical professionals' attitudes towards homosexuality. Psychiatr Danub. 2012 Jun; 24(2):143-51.

8. Mahapatra AB.Reproductive System.In:Essentials of Medical Physiology. $3^{\text {rd }}$ edition. Kolkata: Current Books International; 2007. p. 363-84.

9. Mukherjee JB. Medicolegal aspects of sex and sex related offence. In Karmakar RN, editor. Forensic Medicine \& Toxicology. $4^{\text {th }}$ edition. Kolkata: Academic Publishers; 2011. p. 567-695.

10. Nandy A. Sexual offences and sex perversions. In: Principles of Forensic Medicine including Toxicology. $3^{\text {rd }}$ edition. Kolkata: New Central Book Agency (P) Ltd; 2010. p. 687-720.

11. Ananthanarayanan R, Panicker CKJ. Enterobacteriaceae II: Shigella. In: Textbook of Microbiology. $8^{\text {th }}$ edition. Hyderabad: University Press;2009.p.283-87

12. Ahuja N. Sexual disorders. In: A short textbook of psychiatry. ${ }^{\text {th }}$ edition New Delhi: Jaypee Brothers Medical Publishers (P) Ltd;2006. p.132-6.

13. Ranade K. Medical response to male same-sex sexuality in Western India: An exploration of 'conversion treatments' for homosexuality[Internet]. Health and Population Innovation Fellowship Programme Working Paper, No. 8. New Delhi: Population Council; 2009[cited 2013 Apr 11]. Available from: http://www.popcouncil.org/pdfs/wp/India_HPIF/008. pdf

\section{Looking away does not make things vanish}

We wish to comment on the report by Al Faisal and colleagues published in The Indian Journal of Medical Ethics (1). In that report, the authors claim that economic sanctions imposed in 2011 were the reason behind the devaluation of the local currency, interruption of power supply, scarcity of medical supplies, and degradation of sanitation systems. Nowhere to be found in the report, however, is a description, albeit brief, of what those sanctions are and how they led to these effects. No evidence of cause and effect was presented, no suggested mechanisms, and most grave, no consideration for the interplay between sanctions and an all-out civil war situation that interrupted every sphere of economic activity in the country (2). Such biased and unscientific analysis flies moreover in the face of known facts about the Syrian economy. The political and economic isolation of the Syrian regime is not new, but has allowed Syria, in the past, to ward off most of the global economic crisis of 2008 , and will certainly make it more resilient to economic sanctions per se (3). What is most disturbing in a report about the wellbeing of Syrians in the current conflict still is the lack of any reference to the role of the Syrian regime in inflicting death and hardship on its population. This role has been documented repeatedly by UN agencies, credible media outlets, and the international community, and was behind the mostly regime-targeting sanctions to begin with $(2,4,5)$.

Syria marks a unique case in modern history, where a war is waged by an armed-to-the-teeth regime against its own people with 'all gloves off'. International treaties, norms, and moral constraints of conduct all cease to apply to how the Syrian regime is facing the uprising of people that is approaching its two-year mark (6). The wounded are followed to hospitals to be killed or kidnapped, the dead are mutilated and delivered to their families on the condition that they do not hold funerals, captives are tortured and summarily executed, and civilian areas are indiscriminately bombarded (2,6-8). Furthermore, a distinct hallmark of the Syrian regime's crackdown on the uprising has been the targeting of healthcare facilities and workers. Since the beginning of the uprising, doctors, health professionals and first responders were targeted and killed for nothing else but performing their professional duty towards victims of the conflict (9). The horror stories and scenes emerging from Syria are just the tip of the iceberg in a country that continues to be largely closed to the international press and relief agencies, and where communication and services are usually unavailable in areas of active military operations (2).

To be able to ignore and omit all that and single out sanctions as the cause for the suffering of Syrians requires much more than the talent of distortion.

Wasim Maziak, Professor and Chair, Department of Epidemiology, Florida International University. Director, Syrian Center for Tobacco Studies, FL 33199 USA e-mail: wmaziak@fiu. edu Adam Coutts, Faculty of Human, Social and Political Sciences University of Cambridge, Cambridge UK Fouad Fouad, Syrian Center for Tobacco Studies and Faculty of Health Sciences, American University of Beirut, Beirut, LEBANON

\section{References}

1. Al Faisal W, Sen K, Al Saleh Y. Syria: Public health achievements and the effect of sanctions. Indian J Med Ethics. 2012 Jul-Sep;9(3):151-3.

2. Rovera D, Amnesty International. Syria: Indiscriminate attacks terrorize and displace civilians [Internet]. London: Amnesty International;2012 Sept 14[cited 2013 Jan 14]. Available from: http://www.amnesty.org/ en/news/blog-syria-indiscriminate-attacks-kill-terrorize-and-displacecivilians-2012-09-14

3. Haddad B. The political economy of Syria: realities and challenges. Middle East Policy Council [Internet]. 2010[cited 2013 Jan 14]. Available from: http://www.mepc.org/journal/middle-east-policy-archives/ political-economy-syria?print

4. Friedman U. The five worst atrocities of the Syrian uprising. Foreign Policy[Internet]. 2012 May 29[cited 2013 Jan 11]. Available from: www. foreignpolicy.com/articles/2012/05/29/the_five_worst_atrocities_of_ the_syrian_uprising

5. Delegation of the European Union to Syria [Internet]. Damascus (Syria): Europa. EU restrictive measures - Syria;2012[cited 2013 Jan 14];[about 3 screens]. Available from: http://eeas.europa.eu/delegations/syria/ press_corner/eu_restrictive_measures/index_en.htm

6. Editorial. A medical crisis in Syria. Lancet. 2012 Aug 11;380(9841): 537.

7. Jabbour S. Syria: tales of life, death, and dignity. BMJ. 2012 Mar 7;344:e1691.

8. Morris L. Syrian regime accused of 'atrocity on a new scale' in Daraya The Independent [Internet]. 2012 Aug 27[cited 2013 Jan 11];News Asia:[about 5 screens]. Available from: www.independent.co.uk/news/ world/asia/syrian-regime-accused-of-atrocity-on-anew-scale-indaraya-8082071.html

9. Barmania S. Undercover medicine: treating Syria's wounded. Lancet 2012 May 26; 379(9830): 1936-7. 